\title{
Plastochron index of 'Cabernet Sauvignon' and 'Chardonnay' grapevines in Fronteira Oeste, in the state of Rio Grande do Sul, Brazil
}

\author{
André Ricardo Zeist ${ }^{(1)}$, Tiago Camponogara Tomazetti(2), Márcia Denise Rossarolla ${ }^{(2)}$, \\ Cleber Maus Alberto(3), Clevison Luiz Giacobbo ${ }^{(4)}$ and Leocir José Welter ${ }^{(5)}$
}

\begin{abstract}
(1)Universidade Estadual do Centro-Oeste, Rua Simeão Camargo Varela de Sá, № 03, Vila Carli, CEP 85040-080 Guarapuava, PR, Brazil. E-mail: andre.zeist@bol.com.br (2)Universidade Federal de Santa Catarina, Centro de Ciências Agrárias, Departamento de Fitotecnia, Rodovia Admar Gonzaga, no 1.346, CEP 88034-000 Itacorubi, Florianópolis, SC, Brazil. E-mail: tiago.tomazetti@posgrad.ufsc.br, marcia.rossarolla@posgrad.ufsc.br (3)Universidade Federal do Pampa, Campus Itaqui, Rua Luiz Joaquim de Sá Britto, s/no, Promorar, CEP 97650-000 Itaqui, RS, Brazil. E-mail: cleberalberto@unipampa.edu.br (4)Universidade Federal da Fronteira Sul, Campus Chapecó, Rodovia SC 484, Km 02, Fronteira Sul, CEP 89815-899 Chapecó, SC, Brazil. E-mail: clevison.giacobbo@uffs.edu.br ${ }^{(5)}$ Universidade Federal de Santa Catarina, Campus Curitibanos, Km 03, Ulysses Gaboardy, CEP 89520-000 Curitibanos, SC, Brazil. E-mail: leocir.welter@ufsc.br
\end{abstract}

Abstract - The objective of this work was to estimate the plastochron index of the 'Cabernet Sauvignon' and 'Chardonnay' grapevine varieties in Fronteira Oeste, in the state of Rio Grande do Sul, Brazil. The experiment was conducted in 2010, in a completely randomized design, using 'Cabernet Sauvignon' and 'Chardonnay' grapevines grown in the municipalities of Itaqui, São Borja, and Maçambará, which were referred to as sites 1,2 , and 3, respectively. Phenological monitoring of the varieties was done from the beginning of sprouting until the pruning of canes (green trimming). The daily thermal sum $\left(\mathrm{dTS},{ }^{\circ} \mathrm{C}\right.$ day) was calculated using the cardinal temperatures for node appearance in grapevines $\left(10,25\right.$, and $\left.35^{\circ} \mathrm{C}\right)$, whereas the accumulated thermal sum (aTS, ${ }^{\circ} \mathrm{C}$ day) was obtained by adding up the dTS. The plastochron index was estimated by the inverse of the angular coefficient of the linear regression between the number of nodes per cane and aTS. In all three sites, both 'Cabernet Sauvignon' and 'Chardonnay' required degree-days of $10^{\circ} \mathrm{C}$ and aTS of $810^{\circ} \mathrm{C}$ to complete the cycle from the beginning of sprouting until the end of flowering. The estimated plastochron indexes of the 'Cabernet Sauvignon' and 'Chardonnay' grapevines, in Fronteira Oeste, in the state Rio Grande do Sul, were 40.4 and $49.7^{\circ} \mathrm{C}$ day per node, respectively.

Index terms: Vitis vinifera, degree-days, plant development, temperature, thermal sum, viticulture.

\section{Estimativa do plastocrono das videiras 'Cabernet Sauvignon' e 'Chardonnay' na Fronteira Oeste do Rio Grande do Sul}

Resumo - O objetivo deste trabalho foi estimar o plastocrono das variedades de videira 'Cabernet Sauvignon' e 'Chardonnay' na Fronteira Oeste do Rio Grande do Sul. O experimento foi conduzido em 2010, em delineamento experimental inteiramente casualizado, com as videiras 'Cabernet Sauvignon' e 'Chardonnay' cultivadas nos municípios de Itaqui, São Borja e Maçambará, denominados locais 1, 2 e 3, respectivamente. Realizou-se o monitoramento fenológico das variedades desde o início da brotação até a realização da desponta dos ramos. A soma térmica diária $\left(\mathrm{STd},{ }^{\circ} \mathrm{C}\right.$ dia) foi calculada a partir das temperaturas cardinais para o aparecimento de nós em videira $\left(10,25 \mathrm{e} 35^{\circ} \mathrm{C}\right)$, enquanto a soma térmica acumulada $\left(\mathrm{STa},{ }^{\circ} \mathrm{C}\right.$ dia) foi obtida pela soma da STd. O plastocrono foi estimado pelo inverso do coeficiente angular da regressão linear entre o número de nós por sarmento e a STa. Nos três locais, tanto 'Cabernet Sauvignon' como 'Chardonnay' necessitaram de graus-dia de $10^{\circ} \mathrm{C}$ e STa de $810^{\circ} \mathrm{C}$ para completar o ciclo desde o início da brotação até o fim da floração. Os plastocronos estimados das variedades 'Cabernet Sauvignon' e 'Chardonnay', na Fronteira Oeste do Rio Grande do Sul, foram de 40,4 e $49,7^{\circ} \mathrm{C}$ dia por nó, respectivamente.

Termos para indexação: Vitis vinifera, graus-dia, desenvolvimento da planta, temperatura, soma térmica, viticultura.

\section{Introduction}

According to systematic reports on agricultural production, nearly 984,244 tons of grapes were produced in Brazil in 2016. The state of Rio Grande do Sul is the largest producer of the country, with a cultivated area of nearly 50,000 hectares and an average yield of 8,473 tons per hectare, followed by the

Pesq. agropec. bras., Brasília, v.52, n.4, p.244-251, abr. 2017

DOI: 10.1590/S0100-204X2017000400004 
states of São Paulo, Pernambuco, Santa Catarina, and Paraná (IBGE, 2016). In Rio Grande do Sul, the largest grape production is located in Serra Gaúcha (Mandelli et al., 2003; Mello, 2013); however, new areas within the state are standing out in the national scenario, such as Serra do Sudeste, Campanha, and Fronteira Oeste (Brixner et al., 2010; Radünz et al., 2015; Tomazetti et al., 2015).

Local climate conditions are key factors for the development of grapevines, as well as for the choice of the production system to be adopted (Bem et al., 2015). High-quality crops are affected by radiant energy, air temperature, and rainfall, for example (Liu \& Heins, 2002), and thermal energy is the main responsible for vegetative growth and development, besides playing a crucial role on the phenological behavior of grapevines (Greer \& Weedon, 2013). In this context, studying the responses to soil and climatic conditions has great importance (Tomazetti et al., 2015) since the main classes of grape sugars, i.e., glucose and fructose, are synthesized by photosynthesis in leaves (Miele \& Rizzon, 2013).

Fronteira Oeste, in the state of Rio Grande do Sul, has shown to be a promising area for growing Vitis vinifera $\mathrm{L}$. The region has cold winters, springs with mild temperatures, and hot and dry summers. It should be noted, however, that, before planting vineyards or introducing grape varieties into new regions, the phenological responses to the soil and climatic conditions of the site have to be assessed for an improved technological management (Anzanello et al., 2012).

The phenological performance of grapevine varieties due to climatic conditions can be analyzed by thermal need in terms of degree-days, which is a realistic measure from the biological point of view (Roberto et al., 2005; Brixner et al., 2010; Radünz et al., 2015; Tomazetti et al., 2015). However, an even more attractive way to identify vegetative development as affected by climatic conditions is through the plastochron index (PI), measured in ${ }^{\circ} \mathrm{C}$ day per node. This index consists of the amount of required thermal accumulation for the appearance of successive nodes on the main stem of the plant (Streck et al., 2005, 2008; Paula \& Streck, 2008; Heldwein et al., 2010; Lucas et al., 2012) or, in the case of grapevines, on each cane (Zeist et al., 2016).
The concept of plastochron was used to evaluate various cropped species such as tomato (Coleman \& Greyson, 1976), melon (Streck et al., 2005), soybean (Streck et al., 2008), cotton (Pereira et al., 2010), crambe (Toebe et al., 2010), snap bean (Heldwein et al., 2010), watermelon (Lucas et al., 2012), and sunflower (Souza et al., 2016). These works allowed understanding the phenological behavior of these species, verifying their means of adaptation, defining the most appropriate management practices, and aiding in agricultural zoning through plant growth and development simulation models. Unfortunately, this type of research on grapevine is scarce. One of the few examples is the study by Zeist et al. (2016), who estimated the ${ }^{\circ} \mathrm{C}$ day per node for the 'Marselan' and 'Tannat' varieties in only one growing site.

The advantages of the PI are that it generates mathematical models of growth and development for a plant variety and, when combined with reliable bioclimatic indexes, allows the identification of dates for each phenological phase, even for other geographic regions. In addition, this index can be used to simulate the effects of climate change on agricultural crops.

The objective of this work was to estimate the PI of the 'Cabernet Sauvignon' and 'Chardonnay' grapevine varieties in Fronteira Oeste, in the state of Rio Grande do Sul, Brazil.

\section{Materials and Methods}

The experiment was carried out in a completely randomized design with five replicates and five plants per plot. Two varieties were assessed in 2010: 'Cabernet Sauvignon', due to its red wine production (Burin et al., 2011); and 'Chardonnay', used worldwide for sparkling and white wines (Herrero et al., 2016).

Both varieties were grown in three different sites located in the region of Fronteira Oeste, in the state of Rio Grande do Sul, Brazil: site 1, a commercial orchard located in the municipality of Itaqui $\left(29^{\circ} 18^{\prime} \mathrm{S}\right.$, $56^{\circ} 16^{\prime} \mathrm{W}$, at an altitude of $82 \mathrm{~m}$ ); site 2 , the Campos de Cima vineyard located in the municipality of Maçambará $\left(29^{\circ} 03^{\prime} \mathrm{S}, 55^{\circ} 40^{\prime} \mathrm{W}\right.$, at an altitude of $130 \mathrm{~m}$ ); and site 3, the Quinta do Sino vineyard located in the municipality of São Borja $\left(28^{\circ} 40^{\prime} \mathrm{S}, 55^{\circ} 58^{\prime} \mathrm{W}\right.$, at an altitude of $74 \mathrm{~m}$ ).

Vineyards 1, 2, and 3 were planted in 2004, 2002, and 2001, respectively. In all three orchards, the

Pesq. agropec. bras., Brasília, v.52, n.4, p.244-251, abr. 2017 DOI: 10.1590/S0100-204X2017000400004 
'Sauvignon' and 'Chardonnay' varieties were grafted on 'Paulsen 1103' rootstocks; trained in a trellis system, at a spacing of $4 \mathrm{~m}$ between rows and $1.25 \mathrm{~m}$ between plants, totaling 2,000 plants per hectare; and subjected to green pruning (trimming).

According to Köppen, the climate in the three sites is Cfa, i.e., humid subtropical, with no defined dry seasons and hot summers. Average annual rainfall is $1,700 \mathrm{~mm}$ and annual mean temperature is $19^{\circ} \mathrm{C}$ (Wrege et al., 2011). In site 1, the soil was classified as a Neossolo Regolítico eutrófico léptico (Eutrudent), and, in sites 2 and 3, as a Nitossolo Vermelho distroférrico (Hapludult).

In the three orchards, vine phenological monitoring was carried out from the beginning of sprouting until the pruning of canes. The beginning of sprouting was considered when more than $50 \%$ of the evaluated plants had young shoots above the buds, and pruning was done after flowering, when the calyptra (flower cap) are all fallen and the berries start forming the "fruit set". During the plant cycle, preventive sprayings were applied using registered fungicides and insecticides to control diseases and pests.

During the phenological analysis, the number of visible nodes $(\mathrm{VN})$ was counted weekly for each cane. In sites 1 and 2, sprouting of the 'Cabernet Sauvignon' and 'Chardonnay' grapevines started on September 11; however, in site 3, it began on September 13. In all sites, for both varieties, the last counting of $\mathrm{VN}$ was made in November, about two to five days before pruning.

The PI in each cane was estimated by the inverse of the linear regression coefficient between the number of nodes (NN) per cane and aTS (Streck et al., 2008; Lucas et al., 2012). A single PI value $\left({ }^{\circ} \mathrm{C}\right.$ day per node) was calculated for each plant using the arithmetic mean of the estimated values for the different canes.

The minimum (Tmin) and maximum (Tmax) air temperatures and rainfall were measured daily using thermometers and a rain gauge (Incoterm: Soluções em Medição, Porto Alegre, RS, Brazil), respectively, installed in the orchards. The mean daily air temperature (Tm) was obtained by the arithmetic mean between the daily values of Tmin and Tmax.

The M3.3 method, developed by Tomazetti et al. (2015), was used to determine the daily thermal sum (dTS, ${ }^{\circ} \mathrm{C}$ day). This approach uses base $(\mathrm{Tb})$, optimum (To), and upper (Tu) cardinal temperatures for plant growth, according to the following conditions:
dTS $=[(\operatorname{Tmax}-\mathrm{Tb}) 0.5] \times 1$ day, when $\mathrm{Tm}<\mathrm{To}$ and $\mathrm{Tmin}<\mathrm{Tb}$; dTS = (0) $\times 1$ day, when $\mathrm{Tmax}<\mathrm{Tb}$; $\mathrm{dTS}=(\mathrm{Tm}-\mathrm{Tb}) \times 1$ day, when $\mathrm{Tm}<\mathrm{To}$ and $\mathrm{Tmin}>\mathrm{Tb}$; $\mathrm{dTS}=\{(\mathrm{To}-\mathrm{Tb}) \times[(\mathrm{Tu}-\mathrm{Tm}) /(\mathrm{Tu}-\mathrm{To})]\} \times 1$ day, when $\mathrm{Tm}>\mathrm{To}$ and $\mathrm{Tmax}<\mathrm{Tu}$; dTS $=\{(\mathrm{Tu}-\mathrm{To}) \times[(\mathrm{Tu}-\mathrm{Tm}) /$ $(\mathrm{Tu}-\mathrm{To})]\} \times 1$ day, when $\mathrm{Tm}>\mathrm{To}$ and $\mathrm{Tmax}>\mathrm{Tu}$, being that if $\mathrm{Tmax}>\mathrm{Tu}$, then $\mathrm{Tmax}=\mathrm{Tu}$.

For $\mathrm{Tb}, \mathrm{To}$, and $\mathrm{Tu}$, the values adopted were: 10 , 25 , and $35^{\circ} \mathrm{C}$. The aTS was calculated by adding the individual values of the dTS (aTS $=\Sigma$ dTS) (Streck et al., 2005, 2008; Paula \& Streck, 2008; Heldwein et al., 2010; Lucas et al., 2012).

The PI, the number of canes, and the number of $\mathrm{VN}$ in the last counting were tested for normality and homogeneity. Subsequently, these data were subjected to the analysis of variance individually and jointly. When the F-test was significant, Tukey's test, at 5\% probability, was used to compare differences between means. The data were analyzed using the Assistat software, version 7.6 (Silva, 2013).

\section{Results and Discussion}

The averages for the minimum and maximum air temperatures registered in all sites during the experimental period are shown in Figure 1. The minimum and maximum absolute temperatures ranged from $8.8^{\circ} \mathrm{C}$, on September 15 , to $34.9^{\circ} \mathrm{C}$, on November 28 , in site 1 ; from $6.4^{\circ} \mathrm{C}$, on September 15 , to $34^{\circ} \mathrm{C}$, on November 27, in site 2; and from $8^{\circ} \mathrm{C}$, on September 15 , to $36.5^{\circ} \mathrm{C}$, on November 28 , in site 3 (Figure 1). It should be highlighted that temperatures below $\mathrm{Tb}$ were recorded in September and in October in sites 1 and 2, and throughout the entire study period in site 3 .

For all sites, lower temperatures were common at the beginning of sprouting, being frequently below $\mathrm{Tb}\left(10^{\circ} \mathrm{C}\right)$. However, mean temperatures near To $\left(25^{\circ} \mathrm{C}\right)$ for grapevine growth were common from the beginning of flowering to the last counting of canes. Finally, temperatures above $\mathrm{Tu}\left(35^{\circ} \mathrm{C}\right)$ were recorded only in site 3 , twice in November, on the $8^{\text {th }}$ and $28^{\text {th }}$ (Figure 1).

Both the absolute minimum and mean temperatures in Fronteira Oeste were higher than those obtained for the three largest wine growing regions in the state of Rio Grande do Sul, i.e., Bento Gonçalves in Serra Gaúcha, Encruzilhada do Sul in Serra do Sudeste, and Santana do Livramento in Campanha Gaúcha, during 
the same experimental period (Monteiro et al., 2011). However, the absolute maximum temperature was only higher during September and October, with values close to those of Serra do Sudeste and Campanha Gaúcha only in November. According to the same
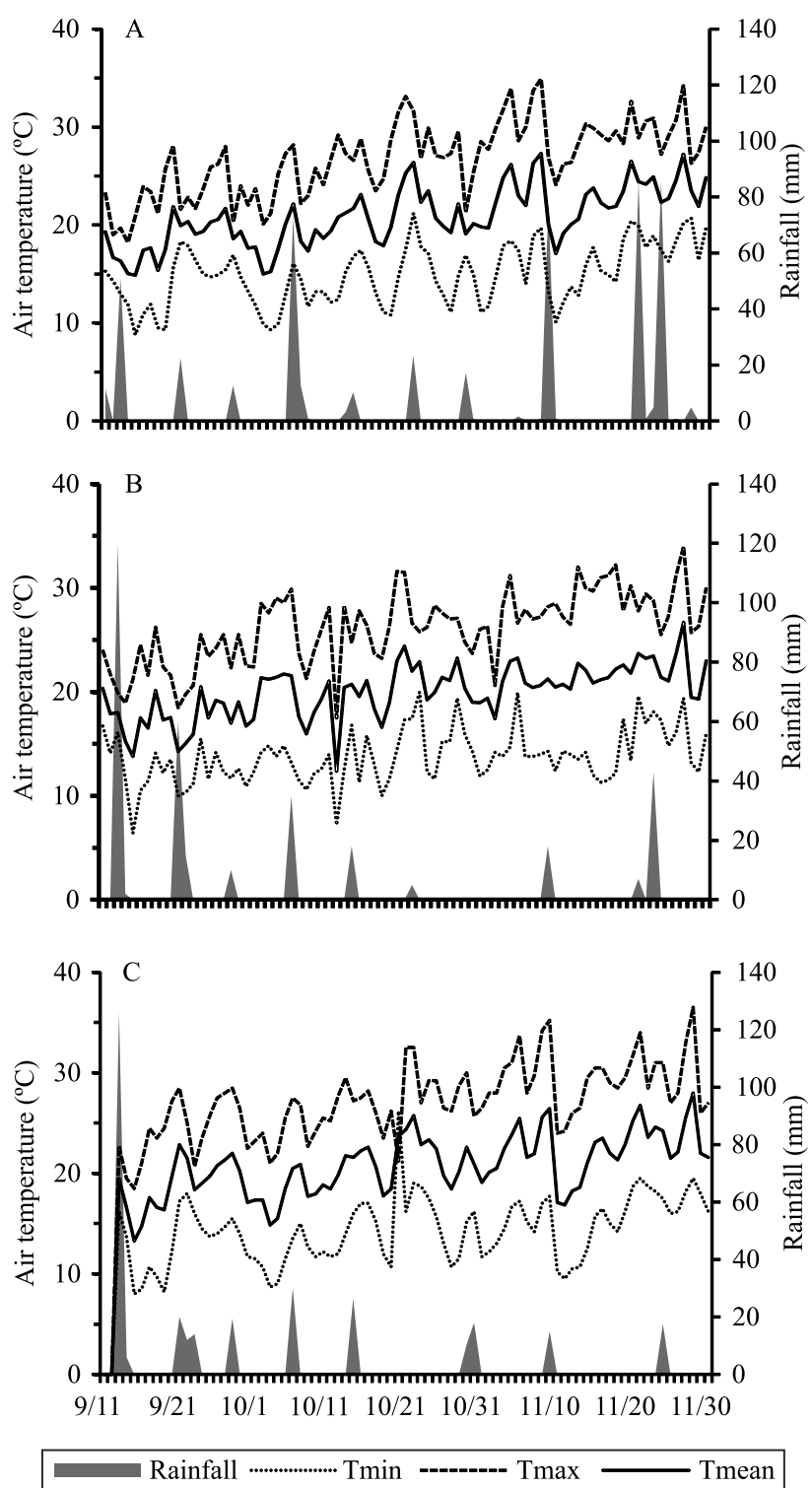

Figure 1. Averages for the maximum (Tmax), medium (Tmed), and minimum (Tmin) air temperatures, as well as for rainfall, registered during the phenological evaluation of the 'Cabernet Sauvignon' and 'Chardonnay' grapevines (Vitis vinifera) grown in: site 1, Itaqui (A); site 2, Maçambará (B); and site 3, São Borja (C), located in Fronteira Oeste, in the state of Rio Grande do Sul, Brazil, in 2010. authors, after the beginning of sprouting, there was a higher frequency of mean temperatures above $18^{\circ} \mathrm{C}$ in Fronteira Oeste. Teixeira et al. (2002) pointed out that temperatures above this threshold stimulate the growth and onset of flowers in wine grapes. Moreover, higher mean temperatures shorten the phenological stages, decreasing the plant cycle, as reported by Roberto et al. (2005) and Sato et al. (2011) in the northwest of the state of Paraná, also in Brazil.

Regarding mean rainfall (Figure 1), considering the monthly average of $141.7 \mathrm{~mm}$ for the studied area (Wrege et al., 2011), it can be inferred that the amounts recorded in September for the three evaluated sites (240.4, 345.0, and $297.5 \mathrm{~mm}$, respectively) and in November for site $1(263.0 \mathrm{~mm})$ were above average. Conversely, rainfall below the monthly average was observed both in October and November for site 2 (58.0 and $68.0 \mathrm{~mm}$, respectively) and site 3 (85.1 and $33.0 \mathrm{~mm}$ ). Independently of its intensity, rainfall was evenly distributed and well-spaced, contributing to the occurrence of dry spells and good insolation. This fact may have favored the production of better quality grapes, as reported by Monteiro et al. (2011).

In general, the weather conditions in Fronteira Oeste, from sprouting to green pruning, have favored growth, flowering, fertilization, and fruit ripening in grapevines. In addition, the higher average temperatures and well-spaced rainfall in the region, which are uncommon in the state of Rio Grande do Sul, may help to restrict the occurrence of diseases.

The beginning of sprouting, for both 'Cabernet Sauvignon' and 'Chardonnay', occurred on September 11 in sites 1 and 2, but on September 13 in site 3. This is considered a great advantage since, in Fronteira Oeste, the risks of frost plummets during the second ten days of September. Brighenti et al. (2013) and Mandelli et al. (2003), while studying grapevines in São Joaquim, in the state of Santa Catarina (above 1,300 m of altitude), and in Serra Gaúcha (around $600 \mathrm{~m}$ of altitude), respectively, reported a delayed sprouting of 'Cabernet Sauvignon', but that 'Chardonnay' plants began to sprout in August, which increases the exposure of this variety to the risk of frosts.

The dTS from the beginning of sprouting until the end of flowering was $10.3,9.9$, and $10.2^{\circ} \mathrm{C}$ day for sites 1,2 , and 3 , respectively, showing variations of 2.7 (site 2) and $14.9^{\circ} \mathrm{C}$ day (site 1) (Figure $2 \mathrm{~A}$ ). By the end of flowering, the aTS values were 821.0, 802.3, and 
$808.3^{\circ} \mathrm{C}$ day for sites 1,2 , and 3 , respectively (Figure 2 B). Therefore, 'Cabernet Sauvignon' and 'Chardonnay' grapevines, grown in Fronteira Oeste, require nearly $810^{\circ} \mathrm{C}$ day (aTS) after the beginning of sprouting to reach the end of flowering, showing an average dTS of $10^{\circ} \mathrm{C}$.

There were no significant interactions between grapevine varieties and cultivation sites regarding the PI, the number of canes per plant, and the mean number of VN in the last counting (Table 1).

Linear regressions for the PI equations, both for varieties and for sites, showed a close relationship $\left(\mathrm{R}^{2} \geq 0.94\right)$ between the NN per cane and aTS (Table 1$)$. These $\mathrm{R}^{2}$ values showed the existence of linearity between the NN and aTS, besides suggesting that
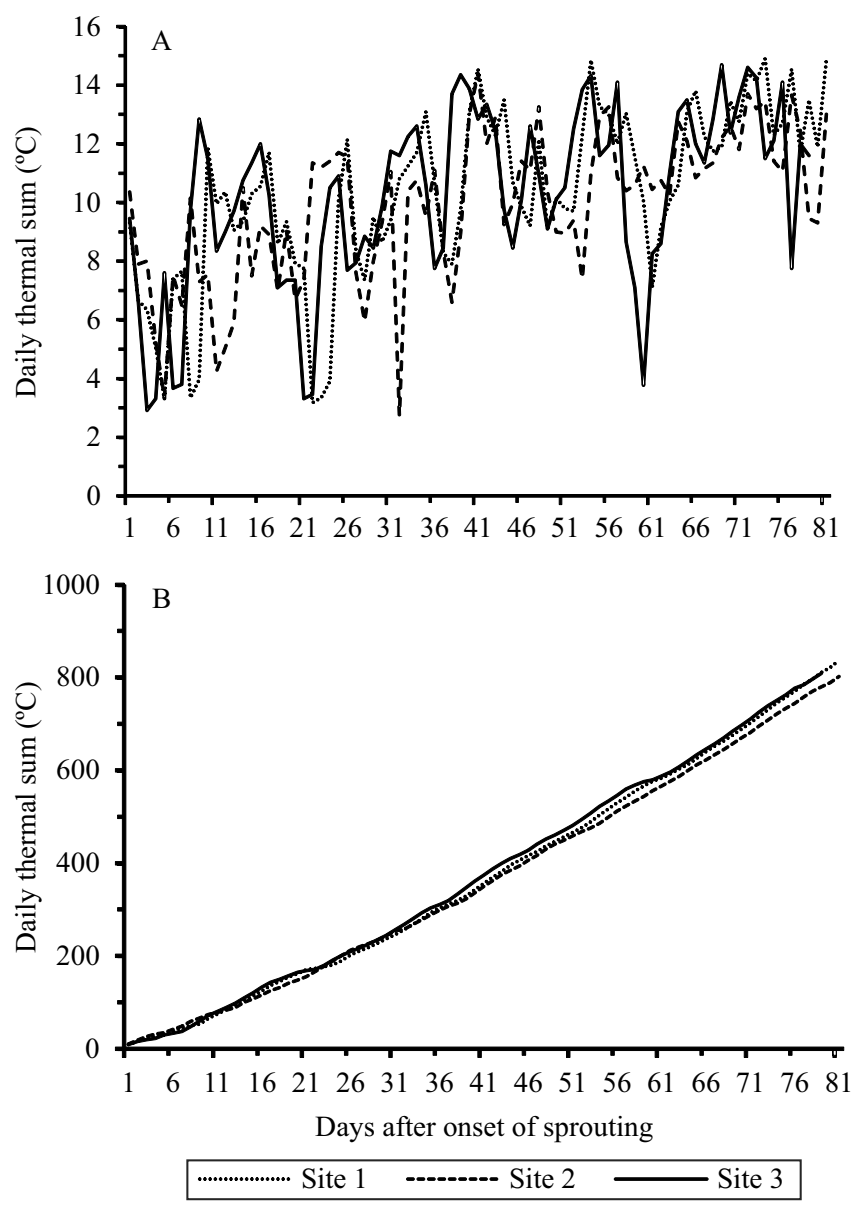

Figure 2. Daily (A) and accumulated (B) thermal sums from the beginning of sprouting to the end of flowering of the 'Cabernet Sauvignon' and 'Chardonnay' grapevines (Vitis vinifera) grown in Fronteira Oeste, in the state of Rio Grande do Sul, Brazil, in 2010. air temperature is the main ecological factor ruling the emergence of nodes. Therefore, it is possible to infer that determining foliar growth (PI) by the linear regression between the $\mathrm{NN}$ and aTS was adequate for grapevine cultivation, as previously reported for other species, such as melon (Cucumis melo L.) by Streck et al. (2005), watermelon (Citrullus lanatus Schrad) by Lucas et al. (2012), snap bean (Phaseolus vulgaris L.) by Heldwein et al. (2010), soybean [Gycine max (L.) Merr.] by Streck et al. (2008), and morning glory (Ipomoea triloba L.) by Paula \& Streck (2008).

The PI of 'Cabernet Sauvignon' and 'Chardonnay' varieties were 40.4 and $49.7{ }^{\circ} \mathrm{C}$ day per node, respectively (Table 1). In other words, from the beginning of sprouting until emergence in the three vineyards, under the same air temperature, the variety 'Cabernet Sauvignon' required 9.3 less ${ }^{\circ} \mathrm{C}$ day per node of thermal energy accumulation for the production of a new node, when compared with 'Chardonnay'. Under normal growing conditions, the PI tends to remain the same from one crop cycle to another, which is a great advantage, giving the mathematical model a broader range (Lucas et al., 2012).

Considering the PI, the 'Cabernet Sauvignon' and 'Chardonnay' varieties demanded less ${ }^{\circ} \mathrm{C}$ day for the emission of nodes when compared with 'Marselan' and 'Tannat' (Zeist et al., 2016), which showed nearly $56.25^{\circ} \mathrm{C}$ day per node for the same evaluation site. However, the above-mentioned authors, using only $\mathrm{Tb}$ to calculate the thermal sum, obtained a mean dTS of $10.72^{\circ} \mathrm{C}$, which is similar to that calculated in the present study for 'Cabernet Sauvignon' and 'Chardonnay'.

Grapevine varieties required more ${ }^{\circ} \mathrm{C}$ day per node than annual crops, such as the 'Hy-Mark' melon hybrid (Streck et al., 2005), with $18.6^{\circ} \mathrm{C}$ day per node; 'Crimson Sweet' watermelon (Lucas et al., 2012), with $23.3^{\circ} \mathrm{C}$ day per node; and 'Macarrão' snap bean (Heldwein et al., 2010), with 23.9 and $21.6^{\circ} \mathrm{C}$ day per node in a protected environment and in the field, respectively. These results might be related to the fact that grapevine is a perennial crop, showing a slower growth and development due to thermal energy when compared with short-cycle crops.

Regarding the number of cane nodes per plant in the three sites, 'Chardonnay' had an average of 15.3, which was significantly higher than that of 'Cabernet Sauvignon'. As for the average number of $\mathrm{VN}$ in the 
Table 1. Plastochron index, coefficient of determination $\left(\mathrm{R}^{2}\right)$, number of canes per plant, and mean number of nodes per cane of the 'Cabernet Sauvignon' and 'Chardonnay' grapevines (Vitis vinifera) grown in Fronteira Oeste, in the state of Rio Grande do Sul, Brazil, in 2010(1).

\begin{tabular}{|c|c|c|c|c|c|c|c|c|c|c|c|c|}
\hline \multirow{2}{*}{$\begin{array}{l}\text { Locali- } \\
\text { zation }\end{array}$} & \multicolumn{3}{|c|}{ Plastochron index $\left({ }^{\circ} \mathrm{C}\right.$ day per node) } & \multicolumn{3}{|c|}{$\mathrm{R}^{2}$} & \multicolumn{3}{|c|}{ Number of canes per plant } & \multicolumn{3}{|c|}{ Number of nodes per cane } \\
\hline & $\mathrm{CS}$ & Chardonnay & Average & $\mathrm{CS}$ & Chardonnay & Average & CS & Chardonnay & Average & $\mathrm{CS}$ & Chardonnay & Average \\
\hline Site 1 & 42.8 & 50.5 & 46.6 & 0.96 & 0.95 & 0.96 & 13.2 & 14.8 & 14.0 & 20.1 & 20.8 & 20.4 \\
\hline Site 2 & 39.1 & 47.0 & 43.1 & 0.98 & 0.98 & 0.98 & 12.8 & 15.2 & 14.0 & 22.0 & 21.7 & 21.9 \\
\hline Site 3 & 39.2 & 51.5 & 45.4 & 0.96 & 0.94 & 0.95 & 12.8 & 15.9 & 14.4 & 20.5 & 19.6 & 20.0 \\
\hline Average & 40.4B & $49.7 \mathrm{~A}$ & - & 0.97 & 0.96 & - & $12.9 \mathrm{~B}$ & $15.3 \mathrm{~A}$ & - & 20.9 & 20.7 & - \\
\hline CV (\%) & \multicolumn{2}{|c|}{13.62} & - & - & - & - & \multicolumn{2}{|c|}{11.01} & - & \multicolumn{2}{|c|}{10.88} & - \\
\hline
\end{tabular}

${ }^{(1)}$ Means followed by equal letters, uppercase in the lines and lowercase in the columns, differ significantly by Tukey's test, at $5 \%$ probability. CV, coefficient of variation.

last counting, there were no significant differences between the varieties, nor between the sites, with VN of 20.9 and 20.7 for 'Cabernet Sauvignon' and 'Chardonnay', respectively (Table 1).

The total number of leaves varies according to the number of cane nodes, presenting a direct relationship with the total leaf area of the plant. The leaf area index is widely known as an indicator of crop yield, since the photosynthetic process depends on light energy interception and on its conversion into chemical energy (Favarin et al., 2002). Consequently, the proper canopy management may favor not only the ripening of berries but also the sensory quality of wines (Borghezan et al., 2011).

The thermal sum calculated to represent the biological time in plants is an attractive and widely used method. Overall, it helps to improve the forecasting of the phenological stages of development and vegetative growth (Streck et al., 2005). Therefore, knowing the PI of 'Cabernet Sauvignon' and 'Chardonnay' varieties is of interest to the winegrowers, in order to determine the duration of each development stage, as well as the beginning and ending of plant growth considering the thermal conditions of each season. Radünz et al. (2012) concluded that knowing the phenology and thermal needs of grapevine varieties is important to decide on the best time to adopt certain crop practices in the orchard, as well as to optimize labor management and improve the rational use of pesticides in crop protection.

In the absence of abrupt variations in climatic conditions, such as excessive/scarce rainfall or temperature variation from one agricultural year to another, the use of thermal sum helps in the management of agricultural crops. Since the cropping cycle occurred at the recommended period, when conditions are considered ideal, plants showed a linear response to temperature regarding development and vegetative growth (Streck et al., 2005; Lucas et al., 2012; Brighenti et al., 2013).

\section{Conclusions}

1. The 'Cabernet Sauvignon' and 'Chardonnay' grapevine (Vitis vinifera) varieties grown in Fronteira Oeste, in the state of Rio Grande do Sul, Brazil, require nearly $810^{\circ} \mathrm{C}$ day to complete their cycle from the beginning of sprouting to the end of flowering.

2. For the 'Cabernet Sauvignon' and 'Chardonnay' grapevines, the plastochron indexes of 40.4 and $49.7^{\circ} \mathrm{C}$ day per node can be used, respectively.

\section{Acknowledgments}

To the wineries Campos de Cima and Quinta do Sino and to the property Mata Solés, for allowing the experiment to be carried out in their production areas and for aiding in this work.

\section{References}

ANZANELLO, R.; SOUZA, P.V.D. de; COELHO, P.F. Fenologia, exigência térmica e produtividade de videiras 'Niagara Branca', 'Niagara Rosada' e 'Concord' submetidas a duas safras por ciclo vegetativo. Revista Brasileira de Fruticultura, v.34, p.366-376, 2012. DOI: 10.1590/S0100-29452012000200008.

BEM, B.P. de; BOGO, A.; EVERHART, S.; CASA, R.T.; GONÇALVES, M.J.; MARCON FILHO, J.L.; CUNHA, I.C. da. Effect of Y-trellis and vertical shoot positioning training systems on downy mildew and botrytis bunch rot of grape in highlands of southern Brazil. Scientia Horticulturae, v.185, p.162-166, 2015. DOI: 10.1016/j.scienta.2015.01.023. 
BORGHEZAN, M.; GAVIOLI, O.; PIT, F.A.; SILVA, A.L. da. Comportamento vegetativo e produtivo de videira e composição da uva em São Joaquim, Santa Catarina. Pesquisa Agropecuária Brasileira, v.46, p.398-405, 2011. DOI: 10.1590/S0100204X2011000400009.

BRIGHENTI, A.F.; BRIGHENTI, E.; BONIN, V.; RUFATO, L. Caracterização fenológica e exigência térmica de diferentes variedades de uvas viníferas em São Joaquim, Santa Catarina - Brasil. Ciência Rural, v.43, p.1162-1167, 2013. DOI: 10.1590/ S0103-84782013005000082.

BRIXNER, G.F.; MARTINS, C.R.; AMARAL, U. do; KÖPP, L.M.; OLIVEIRA, D.B. de. Caracterização fenológica e exigência térmica de videiras Vitis vinifera, cultivadas no município de Uruguaiana, na região da Fronteira Oeste - RS. Revista da Faculdade de Zootecnia, Veterinária e Agronomia, v.17, p.221233, 2010.

BURIN, V.M.; SILVA, A.L. da; MALINOVSKI, L.I.; ROSIER, J.P.; FALCÃO, L.D.; BORDIGNON-LUIZ, M.T. Characterization and multivariate classification of grapes and wines of two Cabernet Sauvignon clones. Pesquisa Agropecuária Brasileira, v.46, p.474-481, 2011. DOI: 10.1590/S0100-204X2011000500004.

COLEMAN, W.K.; GREYSON, R.I. The growth and development of the leaf in tomato (Lycopersicon esculentum). I. The plastochron index, a suitable basis for description. Canadian Journal of Botany, v.54, p.2421-2428, 1976. DOI: 10.1139/b76-256.

FAVARIN, J.L.; DOURADO NETO, D.; GARCÍA, A.G. y; VILLA NOVA, N.A.; FAVARIN, M. da G.G.V. Equações para a estimativa do índice de área foliar do cafeeiro. Pesquisa Agropecuária Brasileira, v.37, p.769-773, 2002. DOI: 10.1590/ S0100-204X2002000600005.

GREER, D.H.; WEEDON, M.M. The impact of high temperatures on Vitis vinifera cv. Semillon grapevine performance and berry ripening. Frontiers in Plant Science, v.4, article 491, p.1-9, 2013. DOI: $10.3389 /$ fpls.2013.00491.

HELDWEIN, A.B.; STRECK, N.A.; STURZA, V.S.; LOOSE, L.H.; ZANON, A.J.; TOEBE, M.; SOUZA, A.T. de; PETERS, M.B.; KARLEC, F. Plastocrono e rendimento de feijão-devagem cultivado sob ambiente protegido e no ambiente externo em semeadura tardia no outono. Ciência Rural, v.40, p.768-773, 2010. DOI: $10.1590 /$ S0103-84782010005000045.

HERRERO, P.; SÁENZ-NAVAJAS， P.; CULLERÉ, L.; FERREIRA, V.; CHATIN, A.; CHAPERON, V.; LITOUXDESRUES, F.; ESCUDERO, A. Chemosensory characterization of Chardonnay and Pinot Noir base wines of Champagne. Two very different varieties for a common product. Food Chemistry, v.207, p.239-250, 2016. DOI: 10.1016/j.foodchem.2016.03.068.

IBGE. Instituto Brasileiro de Geografia e Estatística. Levantamento sistemático da produção agrícola. Rio de Janeiro, 2016. Available at: <www.ibge.gov.br/home/estatistica/ indicadores/agropecuaria/lspa>. Accessed on: Jan. 112017.

LIU, B.; HEINS, R.D. Photothermal ratio affects plant quality in 'Freedom' poinsettia. Journal of the American Society for Horticultural Science, v.127, p.20-26, 2002.

LUCAS, D.D.P.; STRECK, N.A.; BORTOLUZZI, M.P.; TRENTIN, R.; MALDANER, I.C. Temperatura base para emissão de nós e plastocrono de plantas de melancia. Revista Ciência Agronômica, v.43, p.288-292, 2012. DOI: 10.1590/ S1806-66902012000200011.

MANDELLI, F.; BERLATO, M.A.; TONIETTO, J.; BERGAMASCHI, H. Fenologia da videira na Serra Gaúcha. Pesquisa Agropecuária Gaúcha, v.9, p.129-144, 2003.

MELLO, L.M.R. de. Vitivinicultura brasileira: panorama 2012. Bento Gonçalves: Embrapa Uva e Vinho, 2013. 5p. (Embrapa Uva e Vinho. Comunicado técnico, 137).

MIELE, A.; RIZZON, L.A. Intensidades da poda seca e do desbaste de cacho na composição da uva Cabernet Sauvignon. Revista Brasileira de Fruticultura, v.35, p.1081-1092, 2013. DOI: $10.1590 / \mathrm{S} 0100-29452013000400020$.

MONTEIRO, J.E.B. de A.; TONIETTO, J.; SANTOS, H.P. dos; MANDELLI, F. Condições meteorológicas e sua influência na vindima de 2011 no Rio Grande do Sul. Bento Gonçalves: Embrapa Uva e Vinho, 2011. 8p. (Embrapa Uva e Vinho. Comunicado técnico, 108).

PAULA, G.M. de; STRECK, N.A. Temperatura base para emissão de folhas e nós, filocrono e plastocrono das plantas daninhas papuã e corriola. Ciência Rural, v.38, p.2457-2463, 2008. DOI: 10.1590/S0103-84782008000900007.

PEREIRA, L.C.; CAMPELO JÚNIOR, J.H.; FERRONATO, A. Comparação de métodos para estimativa do plastocrono em algodoeiro em condições tropicais. Pesquisa Agropecuária Tropical, v.40, p.213-220, 2010. DOI: 10.5216/pat.v40i2.6716.

RADÜNZ, A.L.; SCHÖFFEL, E.D.; BRIXNER, G.F.; HALLAL, M.O. Efeitos da época da poda sobre a duração do ciclo e a produção de videiras 'Bordô' e 'BRS Violeta'. Revista Científica Rural, v.14, p.213-224, 2012.

RADÜNZ, A.L.; SCHÖFFEL, E.R.; BORGES, C.T.; MALGARIM, M.B.; PÖTTER, G.H. Necessidades térmicas de videiras na região da Campanha do Rio Grande do Sul - Brasil. Ciência Rural, v.45, p.626-632, 2015. DOI: 10.1590/0103$8478 \mathrm{cr} 20140134$.

ROBERTO, S.R.; SATO, A.J.; BRENNER, E.A.; JUBILEU, B.S.; SANTOS, C.E. dos; GENTA, W. Caracterização da fenologia e exigência térmica (graus-dias) para a uva 'Cabernet Sauvignon' em zona subtropical. Acta Scientiarum. Agronomy, v.27, p.183187, 2005. DOI: 10.4025 /actasciagron.v27i1.2144.

SATO, A.J.; JUBILEU, B. da S.; ASSIS, A.M. da; ROBERTO, S.R. Fenologia, produção e composição do mosto da 'Cabernet Sauvignon' e 'Tannat' em clima subtropical. Revista Brasileira de Fruticultura, v.33, p.491-499, 2011. DOI: 10.1590/S010029452011005000079.

SILVA, F. de A.S. e. ASSISTAT: versão 7.6 beta. 2013. Available at: $<$ http://www.assistat.com/>. Accessed on: May 202013.

SOUZA, L.C.C. de; COSTA, A.V.A. da; MOREIRA, W.K.O.; SILVA, E.G. da; SOUZA, A.C. de; SILVA, R.T.L. da. Métodos de soma térmica na determinação de plastocrono de Helianthus annuus L. cultivado em ambiente protegido em Capitão Poço-PA. Nucleus, v.13, p.143-152, 2016. DOI: 10.3738/1982.2278.1640.

STRECK, N.A.; PAULA, G.M. de; CAMERA, C.; MENEZES, N.L. de; LAGO, I. Estimativa do plastocrono em cultivares 
de soja. Bragantia, v.67, p.67-73, 2008. DOI: 10.1590/S000687052008000100008 .

STRECK, N.A.; TIBOLA, T.; LAGO, I.; BURIOL, G.A.; HELDWEIN, A.B.; SCHNEIDER, F.M.; ZAGO, V. Estimativa do plastocrono em meloeiro (Cucumis melo L.) cultivado em estufa plástica em diferentes épocas do ano. Ciência Rural, v.35, p.12751280, 2005. DOI: 10.1590/S0103-84782005000600008.

TEIXEIRA, A.H. de C.; SOUZA, R.A. de; RIBEIRO, P.H.B.; REIS, V.C. da S.; SANTOS, M. das G.L. dos. Aptidão agroclimática da cultura da videira no Estado da Bahia, Brasil. Revista Brasileira de Engenharia Agrícola e Ambiental, v.6, p.107-111, 2002. DOI: 10.1590/S1415-43662002000100019.

TOEBE, M.; LOPES, S.J.; STORCK, L.; SILVEIRA, T.R. da; MILANI, M.; CASAROTTO, G. Estimativa de plastocrono em crambe. Ciência Rural, v.40, p.793-799, 2010. DOI: 10.1590/ S0103-84782010005000054.
TOMAZETTI, T.C.; ROSSAROLLA, M.D.; ZEIST, A.R.; GIACOBBO, C.L.; WELTER, L.J.; ALBERTO, C.M. Fenologia e acúmulo térmico em videiras viníferas na região da Fronteira Oeste do Rio Grande do Sul. Pesquisa Agropecuária Brasileira, v.50, p.1033-1041, 2015. DOI: 10.1590/S0100-204X2015001100006.

WREGE, M.S.; STEINMETZ, S.; REISSER JUNIOR, C.; ALMEIDA, I.R. de. (Ed.). Atlas climático da região Sul do Brasil: estados do Paraná, Santa Catarina e Rio Grande do Sul. Pelotas: Embrapa Clima Temperado; Colombo: Embrapa Florestas, 2011. 336p.

ZEIST, A.R.; ALBERTO, C.M.; TOMAZETTI, T.C.; ROSSAROLLA, M.D.; GIACOBBO, C.L.; WELTER, L.J. Plastochron estimate in grapevine 'Marselan' and 'Tannat' cultivars. Científica, v.44, p.471-476, 2016. DOI: 10.15361/1984-5529.2016v4 4n4p471-476.

Received on October 20, 2016 and accepted on January 26, 2017 